\title{
Livelihood Security Conditions of the Interstate out Migrants of Rural Youth of Assam, India
}

\author{
T.V. Kumar* and U. Barman \\ Department of Extension Education, Assam Agricultural University, Jorhat-13, Assam, India \\ *Corresponding author
}

A B S T R A C T

Keywords

Interstate out

Migration,

Unorganized sector,

Snow ball technique,

Destination place,

Mean working hours.

Article Info

Accepted:

26 June 2017

Available Online:

10 July 2017
The study on causes of interstate out migration of rural youths of Assam was conducted with 150 respondents. The present study was conducted at Hyderabad. The respondents were rural youths of Assam migrated to Hyderabad and worked in unorganized sector. The Snow ball technique was applied to select the respondents. Majority (56.00\%) of the respondents satisfied with their earnings at destination place. Total three fourth $(75.67 \%)$ of the respondents waited for getting a job after the out migration at destination. A majority $(65.34 \%)$ of respondents suffered with asthma problem at destination place. The mean working hours of the respondents at destination was 10.44 hrs. Most of the respondents living in katcha houses in group to save money.

\section{Introduction}

Migration (human) is the movement of people from one place in the world to another for the purpose of taking up permanent or semipermanent residence, usually across a political boundary. People can either choose to move ("voluntary migration") or be forced to move ("involuntary migration"). Migrations have occurred throughout human history. Migration occurs at a variety of scales: intercontinental, intra continental, and inter-regional.

In most of the developing countries, employment in the agricultural sector is decreasing. Many rural areas are undergoing a process of "de-agrarianization", with younger workers seeking to move out of agriculture because of lack of jobs, low incomes and agro-climatic constraints. Increasing numbers of rural people are working in nonagricultural activities in or outside their place of origin in order to diversify their income and reduce risk (Reardon et al., 1998).

FAO (2008) reported that rural out migration tends to exert a downward pressure on agricultural labour per capita. Many literatures reported that movement of migrants away from rural areas, decreased labour available for farm work (Adebayo and Ajayi, 2001; Angba, 2003; Katz, 2003; McCarthy et al., 2006 and Parganiha et al., 2009). It ultimately negatively impacted agricultural production. It was indicated that 
out migration and remittances undermine traditional agriculture. Ofuoku and Chukwuji (2012) revealed that migration impacts negatively on plantation agriculture.

Migration in India is both a historical and present phenomenon. "People have always moved in search of work, in response to environmental shocks and stresses, to escape religious persecution and political conflict. However, improved communications, transport networks, conflicts over natural resources and new economic opportunities have created unprecedented levels of mobility".

Estimates of circular/seasonal migration, involving back and forth movement between a source and a destination, vary from 15 million (NSSO, 2007-2008) to 100 million (Deshingkar and Akter, 2009).

The cities of Mumbai, Delhi, and Kolkata are the largest destinations for internal migrants in India. All three cities absorb large numbers of people from other states across India. Some migrant-sending states are West Bengal, Rajasthan, Madhya Pradesh, Andhra Pradesh, Chhattisgarh, Jharkhand, and Orissa. These states are characterized by very low social and economic development indices and the major urban destinations are the growing economic magnets in an increasingly liberalized Indian economy (Rameez and Varma, 2014).

Rural youth can play an important role in ensuring food security if they are encouraged to involve in farming and the challenges they face are addressed. Over the past few years, rural youth have been shying away from agriculture and globally there is an increasing interest in finding ways of engaging youth in agriculture (IFAD, 2011).

Present study was carried out with following objective.
To find out the livelihood security conditions of the interstate out migrants at destination.

\section{Materials and Methods}

The present study was conducted in Hyderabad city of Telangana state. The state of Telangana comprises of 10 districts among those districts Hyderabad city was purposively selected for the present study. A multi stage sampling design with the snow ball technique was followed in the present study. To obtain the information and response from the present study, total 150 respondents were selected by following snow ball technique. Respondents were rural youth of Assam who migrate to Hyderabad for livelihood and engaged in unorganized sectors/own business. The data collection was carried out through personal interview method with a pre tested questionnaire. The frequencies, percentage, mean, standard deviations, class interval technique were used in analyzing and interpreting the data.

\section{Results and Discussion}

Livelihood security conditions of the out migrant at destination

\section{Job security of the respondent at destination}

Nature of job and salary/wages of the respondent

The table 1 it is indicated that the respondents doing different jobs at destination place. The majority $(61.33 \%)$ respondents worked as security guards under private agencies, out of which 26.00 per cent $(26.00 \%)$ worked in day time and 35.33 per cent $(35.33 \%)$ worked at night time.

Day security guards got Rs. 11,500 per month, night security guards got Rs. 13,000 to 
Rs. 13,500 per month as reported by them. About 8.67 per cent $(8.67 \%)$ of respondents worked as skilled labour like electricians and plumbers, they got wages of Rs. 14000 to Rs. 15000 per month.

The daily wage labour in the construction sector $(28.67 \%)$ received wages of Rs. 350 per day (Monthly Rs. 10500). Two respondents $(1.33 \%)$ started their own business. They run floor tile shop at destination. Their monthly income was Rs. 15,000 to Rs. 16,000 as reported by them. Though all the respondents could not able to find jobs throughout the year, but they need not to wait for more time to find out the next job which was not easy at source. It indicated that their job was perceived to be secured at destination.

\section{Salary/wages satisfaction of the respondents}

The table 2 indicates that the majority $(56.00 \%)$ of the respondents satisfied with their earnings at destination place and 44.00 per cent $(44.00 \%)$ of the respondents was not satisfied with their earnings but they compel to work for maintaining their family.

\section{Frequency of payment of salary/wages}

From the table 3 it was found that the majorities $(70.94 \%)$ of the respondents are getting salary per month and 29.06 per cent $(29.06 \%)$ of the respondents getting wages daily. Here data of the business man were excluded. So no of respondents was 148 .

From the results of frequency of payment of salary it can be concluded that the respondents getting salary in time without any problem but frequency time different for respondents to respondents. Security guards getting salary monthly and construction labours getting daily wages.

\section{Waiting period for job after out migration at destination}

The table 4 indicates that the majority (75.67\%) of the respondents need to wait for employment at destination and 24.33 per cent (24.33\%) of the respondents got a job immediately after the migration. The reason was that these respondents had made contact with the job contractors and conformed job before migration.

The findings indicated that though all the respondents could not able to find jobs throughout the year, but they need not to wait for more time to find out the next job which was not easy at source. They also more or less satisfied with their salary/wages. It indicated that their job was perceived to be secured at destination. This result is in conformity with the results of Breman (1996), Deshingkar et al., (2009), Singleton and Straits (2005), Dewan (2001), Suryanarayanan (2004).

\section{Problems faced by the respondents at work place}

The findings of table 5 were based on the information provided by the respondents who are working at destination as workers. The two respondents who had their own business were not reported any problem. The table 5 indicates that all $148(100 \%)$ migrant worker faced air/dust pollution problem in destination areas. Because of such pollution they suffered with asthma problem. About 91.89 per cent $(91.89 \%)$ of the respondents faced the problem of working extra hours, 95.94 per cent $(95.94 \%)$ of the respondents faced the problem of non availability of pure drinking water at working place, 89.18 per cent $(89.18 \%)$ of the respondents faced the problem of sanitary facilities at working place and 29.05 per cent $(29.05 \%)$ of the respondents faced the problem of working in cement with bare foot and hands. 


\section{Health problems of respondents}

The table 6 indicated that the majority $(65.34 \%)$ of the respondents suffering with asthma and 34.66 per cent $(34.66 \%)$ of the respondents did not suffering with any health problem.

The respondents reported that because of air pollution they suffering with asthma disease.

\section{Daily working hours of migrant}

The table 6 indicates that the majority (37.04\%) of the respondents worked more than 8 hours per day, 36.66 per cent $(36.66 \%)$ of the respondents worked more than 12 hours per day and 26.00 per cent $(26.00 \%)$ of the respondents worked 8 to 10 hours per day. From the results of working hours of migrant, it can be concluded that all the respondents worked more than 8 working hours per day.

Table.1 Nature of job and salary/wages of the respondent

\begin{tabular}{|c|c|c|c|c|}
\hline $\begin{array}{l}\text { Sl. } \\
\text { No. }\end{array}$ & Nature of work & $\begin{array}{l}\text { Wages per month } \\
\text { (In rupees) }\end{array}$ & Frequency & Percentage \\
\hline 1. & Private security guard (at day time) & 11500 & 39 & 26.00 \\
\hline 2. & $\begin{array}{l}\text { Private security guard (as night } \\
\text { watchman) }\end{array}$ & 13000 to 13500 & 53 & 35.33 \\
\hline 3 & Skilled worker (Electrician, Plumber) & 14000 to 15000 & 13 & 8.67 \\
\hline 4. & $\begin{array}{l}\text { Daily wage labour in constriction } \\
\text { field }\end{array}$ & 10500 & 43 & 28.67 \\
\hline 5. & Own business & 15000 to 16000 & 02 & 1.33 \\
\hline & Total & & 150 & 100 \\
\hline
\end{tabular}

Table.2 The Salary/wages satisfaction of the respondents

\begin{tabular}{clcc}
\hline Sl. No. & Satisfaction with earnings & Frequency & Percentage \\
\hline 1 & Satisfied & 84 & 56.00 \\
2 & Not satisfied & 66 & 44.00 \\
\hline & Total & 150 & 100 \\
\hline
\end{tabular}

Table.3 Frequency of payment of salary/wages

\begin{tabular}{clcc}
\hline Sl. No. & Category & Frequency & Percentage \\
\hline 1 & Daily wages & 43 & 29.06 \\
2 & Monthly salary & 105 & 70.94 \\
\hline & & 148 & 100 \\
\hline
\end{tabular}

Table.4 Waiting period for job after out migration at destination

\begin{tabular}{clcc}
\hline Sl. No. & Response category & Frequency & Percentage \\
\hline 1 & Need to wait & 112 & 75.67 \\
2 & Need not to wait & 36 & 24.33 \\
\hline & Total & 148 & 100 \\
\hline
\end{tabular}


Table.5 Problems faced by the respondents at work place

\begin{tabular}{clcc}
\hline Sl. No. & Problems & Frequency & Percentage \\
\hline 1 & Air/dust Pollution problem & 148 & 100 \\
2 & Non availability of pure drinking water at working place & 142 & 95.94 \\
3 & Need to work extra hours on the job & 136 & 91.89 \\
4 & No sewage facilities at work place & 132 & 89.18 \\
5 & Working in cement with bare foot and hands & 43 & 29.05 \\
\hline
\end{tabular}

Table.6 Health problems of respondents

\begin{tabular}{clcc}
\hline Sl. No. & Health problem & Frequency & Percentage \\
\hline 1 & Suffering with asthma & 98 & 65.34 \\
2 & No illness & 52 & 34.66 \\
\hline & Total & 150 & 100 \\
\hline
\end{tabular}

Table.7 Daily working hours of migrant

\begin{tabular}{clccccc}
\hline Sl. No. & Nature of work & Working hours & Frequency & Percentage & Mean & $\begin{array}{c}\text { Standard } \\
\text { deviation }\end{array}$ \\
\hline 1 & $\begin{array}{l}\text { Private security guard at } \\
\text { day time }\end{array}$ & 8 to 10 hrs. & 39 & 26.00 & \\
2 & $\begin{array}{l}\text { Private security guard at } \\
\text { night time }\end{array}$ & More than 12 hrs. & 53 & 35.33 & & \\
3 & $\begin{array}{l}\text { Daily wage labour in } \\
\text { construction fields }\end{array}$ & More than 8 hrs. & 13 & 8.67 & 10.44 & 1.89 \\
4 & $\begin{array}{l}\text { Skilled worker } \\
5\end{array}$ & $\begin{array}{l}\text { Own Business } \\
\text { More than } 8 \text { hrs. }\end{array}$ & 43 & 28.37 & \\
\hline
\end{tabular}

Table.8 Type of house, respondents living at the destination

\begin{tabular}{clcc}
\hline Sl. No. & Type of house & Frequency & Percentage \\
\hline 1 & Katcha & 92 & 61.33 \\
2 & Semi pucca & 41 & 27.33 \\
3 & Pucca & 17 & 11.34 \\
& & & \\
\hline & Total & 150 & 100 \\
\hline
\end{tabular}

Table.9 Perceived food security

\begin{tabular}{clccc}
\hline Sl. No. & Category & Score range & Frequency & Percentage \\
\hline 1 & Rarely & $0-8$ & 150 & 100 \\
2 & Sometimes & $8-16$ & 0 & 0 \\
3 & Often & $16-27$ & 0 & 0 \\
& & & 100 \\
\hline
\end{tabular}

The respondents also reported that they worked more extra hours in comparing to migration. It indicated that they worked hard for their livelihood at destination. 


\section{Accommodation/Housing security}

The respondents got secured accommodation with fewer facilities at destination place. All the respondents were living in rented houses at destination. They reported that house rent is costly at destination.

Type of house, respondents living at the destination

The table 8 indicated that the majority $(61.33 \%)$ of the respondents lived in katcha houses, 27.33 per cent $(27.33 \%)$ of the respondents lived in semi pucca houses and 11.34 per cent $(11.34 \%)$ of the respondents lived in pucca houses at destination.

The study found that a majority of the respondents lived in poor condition at destination. This result is in conformity with result of Deshingkar and Start (2003), Picherit (2012).

\section{Perceived food security}

The table 9 indicates that all $(100.00 \%)$ the respondents perceived that they faced "rarely" any food security problems at the destination.

It was reported during the study that the migrated respondents' families also secure in food at source because the respondents sending money to them regularly. The result is in conformity with the results of Deshingkar (2006), Nandi et al., (2012).

In conclusion, majority of the respondents working as security guards under private agencies. Mean monthly earnings of the respondents was Rs. 12,250 at destination. Majority of the respondents satisfied with their earnings at destination. Majority of the respondents waited for job after the out migration. All the respondents faced the problem air pollution at work place.
Diversification of agriculture is better idea to control the migration because with less existing land of small and marginal farmer's rice centric agriculture not profitable so, Government should encourage the small and marginal farmers to grow remunerative crops instead of rice. It is necessary to provide training, support and guidance for all those occupations which any skill based like carpenters, cobblers, welders, blacksmiths, masons, nurses, tailors, weavers etc. Provision of appropriate support to rural youth livelihood activities and the strengthening of access of young men and women to technical and financial services as well as access to market information is vital for expanding rural employment opportunities. Government should provide fund for establishing new cottage industries in the villages like handlooms and crafts making, pickle, jam and jelly making through financial institutions to rural youth.

\section{References}

Adebayo, K. and Ajayi. 2001. Factors determining the practice of crop livestock integration in the derived savanna and rainforest zones of Nigeria. ASSET Series A. 1(1): 91-100.

Angba, A.O. 2003. Effect of rural-urban migration of youths on agricultural labour supply in Umuahia north local government area of Abia state, Nigeria. J. Advanced Scientific Res., 3(2): 77-83.

Breman, J. 1996. Footloose Labour: Working in India's Informal Sector. Cambridge: Cambridge University Press.

Deshingkar, P. and Daniel, Start. 2003. Seasonal migration for livelihoods in India: Coping, accumulation and exclusion. Overseas Development Institute. Working Paper-220. Retrieved 23 January 2015 from http://www. odi.org.

Deshingkar, Priya, S., Laxman Rao, Saheen Aktar and John Farrington. 2009. The Evolving Pattern of Circular Migration and Commuting: Household Surveys in Andhra Pradesh, ed) in Deshingkar and 
Farrington's Circulation Migration and Multilocational Livelihood Strategies in Rural India, 58-87, Oxford University Press.

Dewan, R. 2001. Ethics of Employment and Exports: Societal Dialogue and Fish Processing Export Units in India, in Oberai, A.S., Sivananthiran, A. and Venkata Ratnam, C.S. eds.) Labour Issues in Export Processing Zones: Role of Social Dialogue, I.L.O: 221- 273.

Food and Agriculture Organization (FAO) of the United Nations. 2008. Agriculture and Rural Development, A FAO prospective. www.fao.org

Food and Agriculture Organization. Retrieved. 16 march 2015 from http://www.cabidirect.org.

IFAD. 2011. Rural Poverty Report 2011: New realities, new challenges: new opportunities for tomorrow's generation. Rome: IFAD.

Katz, E. 2003. The changing role of women in the rural economics of Latin America. In Davis, B. Ed), Current and Emerging Issues for Economic Analysis and Policy Research. 1: 31-66. Latin America and the Caribbean.

McCarthy Carletto, N., Davis, G. and Maltsglou, I. 2006. Assessing the impact of massive out-migration on agriculture. ESA Working Paper, No. 06-14, FAQ, Rome. Retrieved from 12 march 2015 from http://www.iosrjoumals.org.

Nandi, F.N., Chikaire, J., Atoma, C.N., Egwuonwu, H.A. and Echetama, J.A. 2012. Rural youth empowerment: A panacea to rural urban drift. A case study of Ethiopeeast Area of Delta State. Sci. J. Sociol. Anthropol., pp. 100-109.

National Sample Survey Office. 2007-08. Press note on migration in India. Ministry of statistics and programme implementation. Government of India.

Ofuoku and Chukwuji. 2012. The impact of ruralurban migration on plantation agriculture in Nigeria Delta Region, Nigeria. J. Rural Social Sci., 27(1): 137-51.

Pargaih, O.P., Sharma, M.L., Praye, P.M. and Soni, V.K. 2009. Migration effect of agricultural labourers on agricultural activities. Indian Res. J. Extension Education, 9(3): 95-98.

Picherit, D. 2012. Migrant labourers struggles between village and urban migration sites: Labour standards, rural development and politics in South India. Global Labour J., 3(1): 143-162.

Rameez, A. and Varma, D. 2014. Internal Labor Migration in India Raises Integration Challenges for Migrants. Retrieved 17 June 2016 from http://www.migrationpolicy.org/article/inter nal-labor-migration-india-raisesintegration-challenges-migrants

Reardon, T., Stamoulis, K., Balisacan, A., Cruz, M.E., Berdegue, J. and Banks, B. 1998. Rural nonfarm income in developing countries. Special chapter in the state of Food and Agriculture 1998. Food and Agricultural Organization of the United Nations, Rome.

Singleton, R.A. and Straits, B.C. 2005. Approaches to social research. $4^{\text {th }}$ edition. Oxford University Press, New York.

Suryanarayanan, S.S. 2004. Labour laws, contractual parameters and conditions of construction workers: A study in Chennai, NLI Research Studies Series No 50/2004, V.V. Giri National Labour Institute, Noida Uttar Pradesh.

\section{How to cite this article:}

Kumar, T.V. and Barman, U. 2017. Livelihood Security Conditions of the Interstate out Migrants of Rural Youth of Assam. Int.J.Curr.Microbiol.App.Sci. 6(7): 2497-2503. doi: https://doi.org/10.20546/ijcmas.2017.607.354 